\title{
Mapping the Problems of Indonesia's Education System: Lessons Learned from Finland
}

\author{
Sayit Abdul Karim \\ Universitas Teknologi Yogyakarta, Indonesia \\ email: sayit.a.k@uty.ac.id
}

\section{Article History}

Received: 06 August 2021

Reviewed:25 August 2021

Accepted: 21 Sept 2012

Published: 30 Sept 2021

\section{Highlights}

Mapping the problems of Education in Indonesia enables us to improve Indonesia's education systen to achieve international competitiveness in 2025 .

\begin{abstract}
The emergence of having a good education system is one of the hot issues among scholars and stakeholders. Indonesia is now facing various challenges to create a good education system for the better future of its people. This paper examines the problems of Indonesia's education system. A qualitative descriptive research design was applied for the present study. The data in the present study were obtained through observation, library, and documentation study, as well as make use of state of the art sources in the related studies both education in Indonesia and Finland as a role model. Furthermore, the literature review was used to elucidate the findings from the previous studies. The data were analyzed qualitatively by mapping and describing the problems of Indonesia's education system and take a look at the similar aspects of the Finland system. It discusses Indonesia's education problems, including well-trained teacher's deployment, student's tuition fee, class size, and school facilities and access, then further explores Finland's success story in the educational sector as a role model. Mapping the problems of Education in Indonesia enables us to improve Indonesia's education system to achieve international competitiveness in 2025 .
\end{abstract}

Keywords: better education, education quality, Finland, Indonesia

\section{Introduction}

Education is very indispensable for the Indonesian country and has become the main focus of governments' development agenda as it contributes to the nations' competitiveness (Sebayang \& Swaramarinda, 2020; Sulisworo, 2016; Hasbullah, et al., 2011). The education system in Indonesia is established to facilitate its people with an excellent education achievement that bears relevance to life and culture in Indonesia (Bucciarelli, 2013). It is stipulated in Indonesia's constitution that every citizen deserves to obtain an education (Muttaqin, 2018). Besides, the National Education System Law No. 20 of 2003 states that education has functions to develop the ability and build nation characters (Octavia., et al., 2020).

Despite the hard efforts made by the Indonesian government on the education sectors for years, the quality of education in Indonesia is still relatively low (Sebayang \& Swaramarinda, 2020). It is in line with Sudarman, et al., (2016) who say that Indonesia's education problem today is low-quality education. Even though the Indonesian government has been tried hard to reach the target of universal education, inequalities are still the main issue. Furthermore, national development has yet to elevate the quality of people's lives and the well-being of citizens throughout the country equally (Sulisworo, 2016). Moreover, 
Sulisworo's findings revealed that there has been an imbalance in education development in urban and remote areas in the Indonesian regions, especially in Java and outside of Java.

Bearing in mind the emergence of having good quality education, as well as equal access for Indonesian people in the future, many educational scholars, activists, and researchers, have all recognized the need to address Indonesia's educational problems. International competitiveness in 2025 is the ultimate theme of Indonesian education which is stipulated in Indonesia's Development Plan (Sudarman, et al., 2016). However, Indonesia is now facing some challenges to achieve international competitiveness and needs to map the problems towards a better quality of Indonesia Education for the year to come.

It is beneficial for the Indonesian government to observe and learn from the success story of Finland, especially in the education sector. From the review literature and related documents, it has been reported that Indonesia is struggling to gain a high-quality standard of education and equity for its citizenship. Finland's success story in the educational sector will be the role model and discussed in this article. I took Finland as a role model because firstly, Finland has great levels of educational achievement and is one of the world's most literate societies. Secondly, about $99 \%$ complete compulsory basic education; and $94 \%$ of those who start the academic strand of upper secondary school graduate (Sahlberg, 2010). Thirdly, Finland's education system is one of the best in the world and generates the people with the right skills to succeed in a modern knowledge economy (Ruzzi, 2005). The last but not least, Finland's success on the Programme for International Student Assessment (PISA) test was carried out by the Organization for Economic Co-operation and Development (OECD) as a top-scorer since 2000. Is it one of the indicators of the high quality and equality of Finland's educational outcomes and environment (Andere, 2014; Bastos, 2017; Burg, 2018).

Indonesia, a vastly diverse country that is the fourth most populous in the world, with roughly 55 million students, 3 million teachers, and 236,000 schools has to find the best way to improve education outcomes (Julia et al., 2014: 1). According to Heyward \& Sopantini (2011, p. 90), the massive challenge now is to improve the quality of education and increase equity in providing that quality within the country, especially between rural and urban communities. Indeed, the Indonesian government is facing multiple facets of problems in education, and educators and policymakers shall make the right decision for the betterment of Indonesian education (Wijaya, 2019). For those accounts, it is necessary to identify and 
mitigate the problems of Education in Indonesia and learn from Finland's success story to expedite the achievement in the education sector.

Indeed, the issue of Indonesia's education system is very large in its scope; therefore, the researcher narrows the scope of the present study by selecting the Dompu area, one of the regencies in West Nusa Tenggara as the research site. It was selected because some schools are located in very poor and remote areas, have a low quality of education, and very limited access to learning and teaching facilities. Although it does not represent Indonesian education as a whole, portraying the existing condition of those schools in the regencies might be beneficial for us to figure out the education quality in similarly remote areas within the country. Mapping those problems would be a great effort to improve the quality of Indonesia's education in the coming years.

To fill in the gaps, this paper attempts to map and mitigate the problems of the Indonesian education system and takes look at the similar aspect of Finland's for a role model. Therefore, it attempts to map Indonesian education issues. Furthermore, it discusses Indonesia's education problems, then further explores Finland's success story in a similar aspect, and finally offers several ideas, suggestions to improve the Indonesian education system to achieve international competitiveness for the year to come.

\section{Method}

A qualitative descriptive research design was applied for the present study. The data in the present study were obtained through observation, library, and documentation study, as well as make use of state of the art in the related studies both education in Indonesia and Finland. Moreover, observation was conducted in several secondary high schools in Dompu regency, and the other data were taken from previous research findings, e.g. Yusra's research documentation (Providing quality ELT services in English-poor environment), and Julia's, et al (Towards better education: Indonesia's promising path- case study).

Since the present study aims at mapping the problem of Indonesia's education system, indeed, it is very large in its scope. Therefore, the researcher narrows the scope by selecting Dompu, one of the regencies in West Nusa Tenggara as the research site. It was selected because some schools are located in remote areas which are very poor and have a low quality of education and access. Although they do not represent Indonesian education as a whole, portraying the real condition and situation of those schools in Dompu regencies might provide 
us information and insight about what is going on in the similar remote areas within the country so that we could find ways to improve and raise the quality of Indonesia's education in the future.

Furthermore, a literature review was used to elucidate the findings from the previous studies. The data were analyzed qualitatively by mapping and describing the problems of Indonesia's education system and take a look at the similar aspects of the education system in Finland. While discussing the problem, I, at the same time offer several ideas and recommendations relating to what Finland has been done for the improvement of the Indonesian education system shortly.

\section{Findings and Discussion}

\section{Finding}

The data findings from the field observation, documentation, and previous research results revealed that there are several problems encountered by the Indonesian government in the education sector, including but are not limited to school facilities and access to learning media, high tuition fees, big class size, and school teachers' deployment. The problems of Education in Indonesia are mapped and discussed as follows:

\section{School Facilities and Access to Learning Media}

The existence of school facilities is very crucial to support the teaching and learning process. On the teachers' side, the school facilities, such as language laboratories, libraries, journal articles, books, and teaching aids are necessary to support teacher performance. Meanwhile, on the students' side, the facilities may boost their learning achievement. At present, the school facilities and access have become one of the main issues in the Education sector in Indonesia. Some schools and institutions do not have adequate facilities to support the teaching and learning process.

The government of Indonesia needs to upgrade school facilities in rural areas to improve teaching and learning. Mostly, the most common problem is the average age of school buildings. From my field observation in one of the elementary schools in West Nusa Tenggara Province, the school building quality is relatively old. It is about 20 years old and many are in disrepair due to lack of maintenance. Most of the school buildings which are located in the central cities are better than in rural areas. 
Meanwhile, learning media is very limited in number. It is a time for the government to accommodate new teaching and learning styles, which includes a laboratory, comfortable classroom which can facilitate both small and large group students. Ideally, there will be multimedia centers that offer a variety of technological resources, especially for schools that are located in remote areas.

\section{High Tuition Fee}

The government of Indonesia on one hand encourages its people to attend schools and universities to be educated people, but on the other hand, a great number of Indonesian people cannot continue their education due to the expensive tuition fee. Students in Indonesia should pay a lot to go to school. From year to year, the poor family is suffering from high students' tuition fees, especially in this COVID-19 pandemic. Therefore, many of them cannot afford to pay the tuition fee.

It seems that education in Indonesia is still considered expensive in this country. For instance, the tuition fee for pre-school and primary school are ranging from 2 million to 4 million, not to mention secondary and university levels. Apart from the issues, students need to spend extra money on their uniforms, transportation from house to school, meals, and learning materials. This situation makes it impossible for the poor to attend school. Although the government of Indonesia has promoted free of charge for a 12-year mandatory education for the citizen of Indonesia, 'free' does not really mean free of charge because students still have to spend a bunch of money for other school expenses all the year. Therefore, it is not an exaggeration to say the poor might not be at school.

\section{Class Size}

The next issue is about many students in a class. The issue of a great number of students in a class might be experienced by most of the teachers in Indonesia. From my short observation that I did last year in Elementary schools located in Kempo, a rural area in Dompu, West Nusa Tenggara Province, I found out about 40 students were attending a course in one class. The teacher was very tired of managing his big class as students were making noises and did not focus on their tasks given.

Having a big class would influence the effectiveness of the learning and teaching process where the teacher cannot control students effectively due to the noisy and uncomfortable learning situation. Teachers find challenges when teaching a large number of 
students because teachers need extra energy and time to conduct the class and supervise students' activities during learning take place. Besides, teachers do not have much time to see students' progress as they are very busy and tired. Being in such a situation, most teachers are suffering from the pedagogical shortcomings of large classes. Besides, frustration and stress may be experienced by the teachers for the whole day.

Another challenge encountered by teachers teaching students in a large class is in the process of presenting lessons. Teachers find it hard when giving instructional design in a crowded classroom while at the same time, teachers need to create a comfortable atmosphere so that students will interest to participate in the teaching and learning process. Engaging learners actively in the learning process may not be easy in a crowded class. It is hard to imagine how a large class would benefit from school resources such as computers, books, references, and other learning recourses. In short, with a crowded classroom, teachers might find it difficult to measure effectiveness.

\section{School Teachers' Deployment}

Well-trained school teacher's deployment is also a serious problem in the Indonesian Education sector. Indonesia is dealing with the problem of the lack of well-trained teachers who wish to teach in rural schools compared to those who wish to teach in urban schools. As consequence, we shortage of school teachers who teach in remote areas and the ratio of teachers-students is an imbalance.

We hate to acknowledge that the availability of both subject teachers and class teachers in several schools in the border or the remote areas are very limited in numbers while students are large in numbers. The ratio of students and teachers is not a balanced one. Teachers have not been deployed equally in each district within Indonesia. Teachers are more likely to teach in the city. As a result, Indonesia now is facing a serious shortage of teachers, many schools located in rural areas and borders are lack teachers. Despite the program "Indonesia mengajar", launched in 2009, by Anis Baswedan, the former Minister of Education and Culture, teacher shortages remain a serious concern.

\section{Discussion}

Infrastructure and school building quality are important both for students and teachers, especially in the education context to enhance learning and teaching progress. Hasbullah, et 
al., (2011), in their study, confirmed that there is a correlation between comfortable facilities and the level of students' performance. Meanwhile, learning media is a component of learning resources, containing instructional materials that make learning fun and stimulate students to learn (Octavia, Ismiyati., \& Sholikah, 2020; Turi et al., 2017).

Based on my observation in several primary and secondary schools which is located in the remote areas in Dompu regencies (West Nusa Tenggara Province), many schools do have not adequate laboratory facilities, libraries, sports facilities, learning resources, and the like. I was informed that some schools do not have their building to run the teaching and learning process but to occupy other institution facilities. I would suggest the government actively help such institutions by providing a fund to establish the schools in rural areas so that they can survive. Besides, the government must include parents in some school activities, so that the parents' participation will contribute to the improvement of education in the future.

The present findings are supported by the findings of Yusra (2011: p. 158) who has comprehensively identified the effective and the less effective schools in Dompu and Bima regencies, West Nusa Tenggara Province, He went on to say that the problems are caused by several factors such as poor quality of learning materials, dominantly reading-based teaching strategies, and dominantly one-way learning process. Moreover, several other schools might have very poor facilities in the rural areas within the province.

The Indonesian government should provide adequate school facilities and infrastructures to support teaching and learning both in urban and rural schools. The facilities will positively influence the learning environment and achieve students' learning outcomes. In addition, school facilities will be very useful to facilitate teachers' students' interaction, to stimulus attention and skills of learners.

What we can learn from Finland concerning the presence of infrastructure and facility is that the learning and teaching are conducted in a very comfortable atmosphere where every student may choose where they want to sit down. The learning rooms are beautifully designed to attract students' interest to participate in the learning process. Furthermore, the lighting system is perfectly adjusted to the needs of the room size, and the spacious lounges and work areas are available for teachers for casual meetings and quiet places for preparing lessons and transfers. 
In responding to the problem of high tuition fees for students, the government of Indonesia may set up a good program to help the students by providing more scholarship schemes ranging from the primary to university level. In addition, identify the poor family and provide them with financial support. Moreover, the government may also give the students a soft loan for the needy, and then the students should pay back the money in installment to the government when they have got a job later after completing their studies.

According to Sebayang \& Swaramarinda (2020), the adaptability or access to education for the marginalized group is an issue of Indonesian education. They went on to say that Indonesia has not yet provided the right to education to these groups. The government might include Corporate Social Responsibility's budget from enterprises into the educational sector, aiming at supporting the financial difficulties of the poor family and the needy students. Another effort which can be performed by the government is that to control the school policies and practices, as well as to standardize the amount of tuition, especially about the regulation on maximum school tuition that should be paid by students in each province.

Unlike in Indonesia, the students at any level in Finland do not have to pay the tuition fee as it is $100 \%$ subsidized by the government (Flickr, 2016: 1). The government provides special financial aid to support all students. Financial aid is available in the form of a study grant, student loan, and accommodation. The government provides an adequate fund for students' admission, tuition fee for full-time students, and those who need financial assistance. On the contrary, both state and private schools in Indonesia tend to charge high tuition rates.

The number of students per class for instance, in the primary and secondary level in both public and private institutions, is a hotly debated topic. For the problem of class size, ideally, the stakeholders to limit the number of students with a maximum of twenty-five students in a class, because by having not many students in a class classroom teachers can focus on their students' individual needs and give extra assistance to the weak students. It is in line with Suryadarma (2011) who says that the ideal class size for primary schools in Indonesia is twenty-five students per class.

Indonesian teachers often find some difficulties when handling a large number of students with big a size class. To inform a large number of students in a primary and secondary context, Nilan (2003) as cited in Bucciarelli (2013; 7), claims that there are about 
thirty-seven to forty-six students per class in junior secondary and thirty-three to forty-seven students per class in senior secondary classes. Therefore, teachers need to make extra efforts to carry out the teaching and learning in practice, for instance, train students to work in small groups of five to seven students. Teachers can also ask the students to work in pairs by mixing the low-level achievement students with high-level achievement students doing the task and classroom activities.

Unlike in Indonesia, Finland provides as much individual attention as possible by having a small class. A teacher generally will be assigned to the same class at the elementary school level for up to six years. Students and teachers get to know each other and identify the students' needs and learning styles. Much attention will be given to those who have low achievement or slow learners. Teachers handle the class easily during the teaching and learning process because there are only fifteen to twenty students per class.

Teachers would carefully treat their students as the best they can by implementing excellent classroom management during their teaching sessions. To optimize their work and to cope with learning difficulties, teachers would take advantage of the technology to ensure that everyone has time to connect with the teacher. Technology is very useful for teachers and students, especially when they handle large classes. They would use social media such as Facebook, Google meets, email, and other learning platforms to share their learning materials and tasks. In Finland, teachers teach students how to learn instead of what to learn.

Teaching and learning can be conducted not only in the classroom but also can be done outside of the classroom. Students may read the books in a reading corner, on the floor, in the schoolyard, and in parks. Digital learning will be embedded in all assignments. The main focus of the reformed curriculum is teaching young Finns the skills to gain knowledge rather than teaching them the content itself.

According to Jalal et al., (2009) teacher distribution remains a problem until now in Indonesia, leaving an equal proportion of teacher availability in different areas in Indonesia. Furthermore, the Indonesian government is facing various obstacles in developing education in Indonesia, including inadequate quantity, quality, and welfare of teachers (Firman \& Tola, 2008, p. 72). Therefore, the balanced deployment of well-trained teachers to a rural area throughout Indonesia should be done intensively by the government of Indonesia. 
The Indonesian government may increase teachers' salaries and benefit for each classification, for instance, novice and experienced teachers, and especially for those who are assigned in the rural areas. Those teachers must be certified for the course they teach and hold at least a bachelor's degree in teaching, be prepared and ready with ever-changing social, economic, and technology.

One of the ways is through teachers' professional development programs so that they will be ready for any situation and condition in the future. This point is in line with Ornstein \& Levine (2008: p. 394), who assert that fundamental and rapid changes in contemporary society cause teachers to consider fitting themselves into the present and project into the future. The Prospective teachers must have an early assignment and spend a significant amount of time in schools in their preparation.

The lesson learned from Finland on the teacher distribution is that the Finnish government makes a special regulation that all novice teachers shall go out into the countryside and teach for three years or more before trying to have a teaching position in an urban school (Ruzzi, 2005, p.8). Unlike teachers in Indonesia, teachers in Finland are highly trained. The teaching profession is not just a job, it is done by someone who has a high level of education (Muth'im, 2014).

Review literature shows that some of the problems identified in Indonesian education include the low quality of teachers, supervision, the unprofessionalism of teachers in carrying out teacher training (Sebayang \& Swaramarinda, 2020; Kusnandar, 2010). They went on to say that the lack of public appreciation of the teaching profession and quality control of teaching and learning activities in schools which is located in border and remote areas are also the main issues in the Indonesian education sector.

Unlike in Indonesia, teaching is one of the most admired professions in Finland (Finnish Ministry of Education, 2008; Kansanen, 2003; Laukkanen, 2008; McKinsey \& Company, 2010; Sahlberg, 2006; Mardjuki., Lapoto., \& Potradinata, 2017). To become a teacher in Finland, candidates must have first received at least their master's degree in education and a high degree of pedagogical studies which is fully subsidized by the government (Varjo, Kalalahti., \& Kauko, 2019; Niemi, 2015).

One of the reasons students in Finland does very well in the teaching profession is because they have been gone through extensive training conducted by the government. It has 
outstanding teacher preparation. The authority of Finland only selects the best candidate for teachers. Thousands of applicants apply to a university program for teacher education at the primary level, only 700 are accepted (Morgan: 2014). These efforts have been done for sake of students' needs to have highly qualified teachers to teach them (Popa, Laurian, \& Fitzgarald, 2015).

In Finland, teachers are selected from the top $10 \%$ of graduates and turn down thousands of students annually. The best and brightest candidates have to pass a series of interviews and personality screenings, designated to determine their natural ability and drive to teach. These national requirements guarantee that the standard of teacher education remains high. Teaching, as a high profession as much as medical doctors, lawyers, and architects in Finland, has a strong scientific orientation, and therefore they are prepared for research basedteaching practice (Bastos, 2017; Sahlberg, 2006). The balance between theoretical and practical knowledge in the program assists young teachers master various teaching methods and science of teaching and learning.

As the school teachers are one of the pillars of excellence and success of education, the government of Indonesia may upgrade the skills and knowledge of teachers and set higher standards for becoming teachers and conduct a very strict teacher selection. Besides, train the candidates intensively before having the teaching profession. It can be done in the form of a special program of the teaching session, pre-service teacher program, and take the national exam for the teaching profession (both performance and competence). Besides, the government provides a chance to have continued professional development, and promotes the use of ICT programs in classroom teaching so that the learning can be accelerated, enjoyable, efficient and effective, and most preferred by the students.

The use of ICT programs can be done from the teaching preparation, teaching practice, and teaching evaluation. All of these activities should be evaluated by independent experts and authorities for quality teaching improvement or quality assurance. Moreover, at the university level, the government should also urge the lecturers to conduct research, attend seminars or conferences of scientific works, as well as disseminate it each semester so that they can keep developing academically and professionally.

It is very important to hire very high motivated teachers who want to teach in any place in Indonesia and possess a positive attitude and believe in the teaching profession. The 
idea is supported by Uztosun \& Topkaya (2017) who says that it is critical to recruiting highly motivated teachers because teachers' enthusiasm and job commitment are regarded as basic determinants influencing learners' motivation and their careers.

Apart from the teacher's deployment, the issue of the quality of teachers is also highlighted. They are considered to have low teaching quality and knowledge in their field. In fact, in Indonesia, many graduates do not have enough knowledge and pedagogical competencies or teaching skills as shown by teachers in Finland. Concerning this issue, Yusra (2011: 157) in his research reported that the factors contributing to the failure in obtaining the minimum standard performance are teacher's lack of English competence, pedagogic skills, and experience. The government expected teachers to assume more extensive responsibilities at their schools and to experiment with innovative pedagogies in the classroom (Bjork, 2005: $83)$.

Despite the aforementioned problems, we have to acknowledge that not all of Indonesia's education systems are bitter and sour. Indonesian government through the Ministry of Education and Culture has made some progress in the education sector. From many countries' experiences, education quality and equity have an important role in sustainable nation competitiveness.

\section{Conclusions and Suggestions}

\section{Conclusions}

Several important points to be highlighted concerning with the problem of Education system in Indonesia, they are; the imbalance of well-trained teacher's distribution throughout the country, high student's tuition fee, the big number of students in a class, and the availability of school facilities and access to the better education. Those points are needed to work on immediately on their natural need bases and authorities together with all stakeholders shall work hand in hand to improve the quality and equity of education in Indonesia to be able to achieve international competitiveness in 2025.

It is important to notice that Finland's success story has not 'fallen from the blue sky like lightning on a sunny day'. The success story of Finland in the education sector results from high efforts and strong commitment from all stakeholders in the last 70 years. Therefore, a better Indonesia's education system is very necessary for the society promotes the growth and development of the Indonesian country for the year to come. 


\section{Suggestions}

The emergence of having a good quality of education is a must and therefore, I suggest that the Indonesian government as the policymaker take immediate necessary actions to create a good system and implement the strategies as a lesson learned from the success story of Finland as a role model, one of the top rank countries performing the best education system in the world. Indeed, the Indonesian education system should be directed to the improvement of education for all the people of Indonesia. This can be done by working hand in hand among the government officials and all stakeholders in the educational sector.

\section{References}

Andere, E. (2014). São os docentes cruciais para o desempenho acadêmico? O sucesso educativo da finlândia em perspectiva comparada. Education Policy Analysis Archives, 23. https://doi.org/10.14507/epaa.v23.1752.

Bastos, B. R. M. (2017). The surprising success of the Finnish educational system in a global scenario of commodified education. Revista Brasileira de Educação, 22(70), 802-825. https://doi.org/10.1590/s1413-24782017227040.

Bjork, C. (2005). Indonesian Educational: Teachers, Schools, and Central Bureaucracy. Taylor \& Francis. Routledge Newyork \& London. https://doi.org/10.4324/9780203959015.

Bucciarelli, A. (2013). Standardized Chaos: A Portrait of the Indonesian Education System. Research Paper. SIT Graduate Institute/SIT Study Abroad. Accessed from http://digitalcollections.sit.edu/cgi/viewcontent.cgi?article $=25$ $56 \&$ context=ispcollection.

Burg, C. (2018). Finnish Education in the 21st Century: Paradoxes and Visions. I.E.: Inquiry in Education, 10(1), 8. Retrieved from: https://digitalcommons.nl.edu/ie/vol10/iss1/8. July 4, 2021.

Firman, H., \& Tola, B. (2008). The Future of Schooling in Indonesia. Journal of International Cooperation in Education. 11 (1), 71-84.

Flickr, W. (2016). 26 Amazing Facts About Finland's Unorthodox Education System. Retrieved on July 5, 2021, from: https://edutechers.com/26-amazing-factsabout-finlands-unorthodox-education-system.

Hasbullah, A., Yusoff, W. Z. W., Ismail, M., \& Vitasari, P. (2011). A framework study of school facilities performance in public primary school of Batubara district in Indonesia. Procedia - Social and Behavioral Sciences, 15(October), 3708-3712. https://doi.org/10.1016/j.sbspro.2011.04.360.

Heyward, \& Sopantini. (2011). Indonesia: The Challenges of Quality and Equity in Education. Education development in Indonesia/the missing political and cultural dimensions. 71-93.

Jalal, F., Samani, M., Chang, M.C., Steven, R., Ragatz, A.B., \& Negara, S.D. (2009). Teacher certification in Indonesia: A Strategy for Teacher quality improvement. (Report No. 48578). Retrieved from https://learningportal.iiep.unesco.org/es/biblioteca/teacher-certification-in-indonesiaa-strategy-for-teacher-quality-improvement. 
Julia, T., Wales., \& Syamsulhakim. (2014). Towards Better Education: Indonesia's Promising Path: Case Study Summary. London: Overseas Development Institute.

Kansanen, P. (2003). Teacher education in Finland. Current models and new development. International Approaches in teacher education within higher education in Europe. 85108. Retrieved from https://www.helsinski.fi/-pkansane/articles.html

Kusnandar. (2010). "Teaching Profession". Jakarta: Bumi Aksara.

Laukkanen, R. (2008). Finish Strategy for high-level education for all. Government and performance of education system. Netherlands: Springer.

Mardjuki, M. S., Potradinata, S. L. A., \& Gusman, A. A. (2017). Secret To Finland's education success : A reflection for education in Indonesia (a literature review). English Language and Literature International Conference (ELLiC), 13(6), 224-230. https://pddi.lipi.go.id/1st-english-language-and-literature-international-conferenceellic-proceedings.

McKinsy \& Company. (2007). How the world's best-performing school system come out on top. Retrieved from http://www.mckinsey.com/locations/ukireland/publication/pdf/Education_reprt.pdf.

Ministry of Education. (2008). OECD PISA survey. Finland's success in the PISA survey. Finland. Retrieved from http://.www.minedu.fi/OPM/Koulutus/artikelit/pisa:tutkimus/index.html?lang=en.

Morgan.' H. (2014). The Education System in Finland: A Success Story Other Countries Can Emulate. Review of Research, 453-457. Accessed from http://www.tandfonline.com/doi/full/10.1080/00094056.2014.983013.

Muth'im, A. (2014). Understanding and Responding to the Change of Curriculum in the Context of Indonesian Education. American Journal of Educational Research, 2(11), 1094-1099. https://doi.org/10.12691/education-2-11-15.

Muttaqin, T. (2018). Determinants of Unequal Access to and Quality of Education in Indonesia. Jurnal Perencanaan Pembangunan: The Indonesian Journal of Development Planning, 2(1). https://doi.org/10.36574/jpp.v2i1.27.

Niemi, H. (2015). Teacher professional development in Finland: Towards a more holistic approach. Psychology, Society and Education, 7(3), 279-294. https://doi.org/10.25115/psye.v7i3.519.

Nilan, P. (2003). Teachers' Work and Schooling in Bali. International Review of Education ,49(6), 563-584. Retrieved August 4, 2021, from http://www.jstor.org/stable/3445398

Octavia, E,T., Ismiyati., \& Sholikah, M. (2020). How Do School Facilities Affect School Quality? Case Study in Vocational High School at Pati, Indonesia. KnE Social Sciences, 2020(19), 865-881. https://doi.org/10.18502/kss.v4i6.6648

Ornstein, A. C. \& Levine, D. U. (2008). Foundations of Education. Boston: Houghton Mifflin Company.

Ruzzi, B.B. (2005). Finland Education Report. National Centre on Education and the Economy. Retrieved from http://www.ncee.org/wp-content/uploads/2010/04/Finland-Education-Report.pdf.

Popa, C., Laurian, S., \& Fitzgerald, C. (2015). An insight Perspective of Finland's Educational System. Procedia - Social and Behavioral Sciences, 180(December), 104-112. https://doi.org/10.1016/j.sbspro.2015.02.092.

Sahlberg, P. (2006). Raising the Bar : How Finland Responds To the Twin. World Bank, 1, 
$1-26$.

Sahlberg, P. (2010). The Secret to Finland's Success: Educating Teachers.

Research Brief. Accessed from:

https://pdfs.semanticscholar.org/a6a0/b0091c0f61493e9ea6ed98a0bc7cf90 e207d.pdf.

Sebayang, K. D. A., \& Swaramarinda, D. R. (2020). Educational policy implementation in Indonesia: The art of decision making. International Journal of Scientific and Technology Research, 9 (1), 1286-1290.

Sudarman, E., Sawitri, N. N., \& Budiono, G. L. (2016). Development of Education in Indonesia : an Effort To Strengthening Innovation Systems and International Competitiveness. Vector European Revista Ştiinţifică, 3, 14-20.

Sulisworo, D. (2016). The Contribution of the Education System Quality to Improve the Nation's Competitiveness of Indonesia. Journal of Education and Learning (EduLearn), 10(2), 127-138. https://doi.org/10.11591/edulearn.v10i2.3468...

Suryadarma, D. (2011). The Quality of Education in Indonesia: Weighed, Measured, and Found Wanting Let's start with a test. Presented at Forum Kajian Pembangunan Seminar Series SMERU Research Institute, Jakarta. May 18, 2010. Retrieved from: https://crawford.anu.edu.au/acde/ip/pdf/lpem/2011/Daniel_2011a.pdf\%3E. July 3, 2021.

Turi, L. O., Ahiri, J., Dunifa, L., \& Ardiansyah, L. M. (2017). Identifying the Problems of Indonesian Primary School Teachers in Developing Learning Devices. International Journal of Education, Learning and Development, 5(8), 55-64. www.eajournals.org

Uztosun, MS., \& Topkaya, EZ. 2017. A Cross-national Study into Pre-service EFL. Teachers' Career Choice Motivations in Germany, Japan, and Turkey. The ASIAN EFL Journal Quarterly, 19 (2), 83-110.

Varjo, J., Kalalahti, M., \& Kauko, J. (2019). Overview of Primary Education (Finland). Bloomsbury Education and Childhood Studies, January. https://doi.org/10.5040/9781350995932.0018.

Wijaya, H. (2019). Redefining the Success of Education: Where Indonesia Has Excelled and Where It Has Not. Jurnal Humaniora, 31(2), 118. https://doi.org/10.22146/jh.v31i2.36532.

Yusra, K. (2011). Providing Quality ELT Services in English -Poor Environment: The Asian EFL Journal Quarterly, 17 (3), 153-164. Retrieved from: https://www.researchgate.net/publication/331312492_Providing_Quality_ELT_Servic es_in_English-poor_English_Environments_A_Lesson_from_Indonesia. 